\title{
PEMAHAMAN GURU TERHADAP KETERAMPILAN PROSES SAINS (KPS) DAN PENERAPANNYA DALAM PEMBELAJARAN IPA SMP DI SALATIGA
}

\author{
Adriana Agustina Lonny Hamadi, Desy Fajar Priyayi, dan Susanti Puji Astuti \\ Universitas Kristen Satya Wacana \\ e-mail: dhiana.hamadi@gmail.com
}

\begin{abstract}
Abstrak
Penelitian ini bertujuan untuk mengetahui pemahaman guru IPA SMP di Salatiga mengenai keterampilan proses sains dan bagaimana penerapannya dalam pembelajaran. Penelitian ini merupakan penelitian survei dengan mengunakan pendekatan kuantitatif non eksperimen. Subjek penelitian adalah seluruh guru IPA di 6 SMP di Salatiga. Teknik pengumpulan data menggunakan wawancara, kuesioner dan dokumentasi. Data yang diperoleh dianalisis secara deskriptif berdasarkan tahap pengumpulan data, reduksi data, penyajian data, dan penarikan kesimpulan. Hasil penelitian menunjukkan sebanyak $50 \%$ guru memiliki pemahaman tentang KPS dalam kategori baik dan 50\% guru memiliki tingkat pemahaman yang cukup. Guru telah melakukan kegiatan-kegiatan yang mengajak siswa ke arah pengembangan KPS. Dari aspek dengan nilai persentase tertinggi hingga terendah antara lain: menginterpretasi data (85\%), mengamati $(71 \%)$, mengklasifikasi (57\%), merumuskan masalah (57\%), menyimpulkan (50\%), mengkomunikasi $(50 \%)$, mengindentifikasi (50\%), mengukur (42\%), dan melakukan ekperimen (28\%). Aspek KPS telah diterapkan namun belum maksimal karena kurangnya waktu belajar mengajar, belum juga memiliki laboratorium dan juga lembar kerja siswa (LKS) dan rendahnya motivasi siswa.
\end{abstract}

Kata kunci : Pemahaman Guru, Pembelajaran, KPS

\begin{abstract}
The purpose of this research was to measure the understanding of junior high school science teachers in Salatiga about science process skills (SPS) and how they applied it in learning process. This research was a survey research using a non-experimental quantitative approach. The research subjects were all science teachers in 6 different junior high schools in Salatiga. Data collection techniques were interviews, questionnaires and documentation. The data were analysed descriptively based on the stages of data collection, data reduction, data presentation, and conclusion. The results showed that $50 \%$ of teachers had an understanding of KPS in good category and $50 \%$ of teachers had a sufficient level of understanding. The teacher has carried out activities that invite students towards SPS development. Indicators with the highest to lowest percentage values were interpreting data skill (85\%), observing skill $(71 \%)$, classifying skill $(57 \%)$, formulating problems skill $(57 \%)$, concluding skill $(50 \%)$, communication skill $(50 \%)$, identifying skill $(50 \%)$, measuring skill (42\%), and experiment skill $(28 \%)$. KPS aspects had been iniffectively implemented for some reasons; lack of teaching and learning time allocation, limitation of laboratory facility and student worksheets (LKS) and students' low motivation.
\end{abstract}

Keywords: Teacher Understanding, Learning, SPS 


\section{PENDAHULUAN}

IImu Pengetahuan Alam (IPA) merupakan bagian dari sains yang terbentuk dan berkembang dengan suatu proses ilmiah. Kurniawan \& Fadloli (2015) menyatakan bahwa IPA merupakan kumpulan dari pengetahuan dan bagaimana proses untuk dapat mengetahui pengetahuan tersebut. Pembelajaran IPA seringkali menggunakan metode ilmiah untuk dapat mengetahuai kemampuan berpikir, berkerja dan bersikap ilmiah serta dapat mengkomunikasikannya sebagai aspek penting pada pengalaman belajar secara langsung melalui pengembangan keterampilan proses dan sikap ilmiah.

Pembelajaran IPA mengarah pada kegiatan yang memungkinkan peserta didik tidak hanya mempelajari mengenai pengetahuan yang mengarah pada keterampilan berpikir yang dapat menghasilkan fakta, konsep, prinsip, hukum, teori saja melainkan belajar IPA juga tentang pengetahuan prosedural yaitu belajar tentang bagaimana cara memperoleh informasi melalui kegiatan ilmiah yang berbasis pada KPS. Rustaman (2015) menjelaskan bahwa keterampilan proses sains dituntut dalam pembelajaran IPA dan telah menjadi bagian yang tak dapat dipisahkan dalam pembelajaran IPA. Terdapat 2 kelompok KPS, yaitu meliputi keterampilan dasar dan keterampilan terintegrasi. Keterampilan proses dasar merupakan keterampilan untuk dapat melakukan observasi, menginferensi, mengukur, mengkomunikasi, mengklasifikasi, dan dapat memprediksi, sedangkan proses yang dimaksud dengan keterampilan proses terintegrasi merupakan keterampilan yang mampu untuk mengontrol variabel, memberikan definisi operasional, dapat merumuskan hipotesis, menginterpretasikan data, dan dapat melakukan eksperimen. Aydogdu (2015) mengklasifikasikan keterampilan proses sains menjadi dua yaitu keterampilan proses dasar meliputi: keterampilan observasi, mengklasifikasikan, mengukur, dan menyimpulkan. Sedangkan keterampilan proses sains terintegrasi meliputi: keterampilan merumuskan hipotesis, mengidentifikasi dan mengontrol variabel, keterampilan melakukan eksperimen, dan menginterpretasi data.

Pemahaman guru mengenai pembelajaran IPA sangatlah penting untuk dapat mengembangkan pengetahuan dan pembelajaran dengan hakikat-hakikat sains itu sendiri. Rustaman (2005) menjelaskan bahwa peran guru sangat penting dalam proses belajar mengajar, diantaranya sebagai penyampaian informasi, pengelola kelas, fasilitator, mediator dan evaluator. Guru IPA harus dapat menguasai pengetahuan, cara kerja, dan keterampilan di bidangnya. Hal ini menunjukkan bahwa selain penguasaan konsep, guru mendukung dan berperan dalam mengembangkan keterampilan-keterampilan dasar biologi serta keterampilan proses sains. Hasil penelitian Aydogdu (2015) menunjukkan KPS guru yang lebih senior mengalami penurunan karena guru tidak mengembangkannya. Calon guru perlu memperoleh pemahaman yang baik tentang pembelajaran sains secara teori maupun secara praktek. Mengingat pentingnya 
pemahaman guru tentang KPS, maka perlu dilakukan penelitian dengan tema pemahaman guru terhadap KPS dan penerapannya dalam pembelajaran IPA SMP di Salatiga.

\section{METODE}

Penelitian ini menggunakan survei dengan pendekatan kuantitatif non eksperimental. Penelitian non eksperimen adalah penelitian yang dilakukan tanpa adanya suatu perlakuan terhadap variabel penelitian.Penelitian ini dilaksanakan di 6 SMP di Salatiga, pada bulan April sampai bulan Juni 2018. SMP yang menjadi sampel penelitian yaitu SMP Negeri 3 Salatiga, SMP Negeri 4 Salatiga, SMP Negeri 9 Salatiga, SMP Kristen 2 Salatiga, SMP Laboratorium Satya Wacana, dan SMP Stella Matutina. Subyek yang diteliti adalah guru-guru IPA SMP dari 6 sekolah dengan jumlah 14 guru di kota Salatiga. Teknik pengumpulan data yang digunakan dalam penelitian ini adalah menggunakan teknik wawancara, kuesioner dan dokumentasi. Wawancara dilakukan oleh peneliti dengan mengajukan pertanyaan-pertanyaan terstruktur sesuai pedoman wawancara kepada guru sebagai narasumber. Musfiqon (2012) menyatakan tujuan dari penerapan teknik wawancara adalahmendapatkan informasi dan data sesuai dengan masalah penelitian. Selain itu digunakan kuesioner dalam bentuk kuesioner terbuka dan kuesioner tertutup untuk mendapatkan data tentang pemahaman guru mengenai KPS. Penerapan teknik kuesioner dilakukan dengan cara memberi pertanyaan-pertanyaan atau pernyataan tertulis kepada respoden untuk dijawab dengan menggunakan instrumen berupa lembar kuesioner (Sugiyono, 2015). Teknik dokumentasi dilakukan dengan mengumpulkan data berupa hasil rekaman hasil wawancara.

Data yang diperoleh dari hasil penelitian ini dianalisis dengan teknik deskriptif kualitatif. Data yang diambil merupakan data hasil wawancara, pengisian kuesioner, dan dokumentasi. Data hasil kuesioner pemahaman guru duhitung dengan rumus sebagai berikut:

Tingkat pemahaman guru $=\frac{\text { Jumlahskorperolehan }}{\text { Jumlahskormaksimal }} \times 100 \%$

Persentase pemahaman guru dikelompokkan menjadi empat kategori dengan menggunakan rumus menurut Mardapi (2008) yang tersaji pada Tabel 1.

Tabel 1. Konversi Skor Menjadi Skala 4

\begin{tabular}{llll}
\hline No & Rentang skor & Nilai & Kategori \\
\hline 1 & $\mathrm{X} \geq \bar{X}+1 . \mathrm{SBX}$ & $\mathrm{A}$ & Sangat Baik \\
2 & $\bar{X}+1 . \mathrm{SBX}>\mathrm{X} \geq \bar{X}$ & $\mathrm{~B}$ & Baik \\
3 & $\bar{X}>\mathrm{X} \geq \bar{X}-1 . \mathrm{SBx}$ & $\mathrm{C}$ & Cukup \\
4 & $X<\bar{X}-1 . S B X$ & $D$ & Kurang \\
\hline
\end{tabular}




\section{Keterangan :}

$$
\begin{aligned}
\bar{X}= & \text { Rerata-rata skor secara keseluruhan } \\
& \frac{1}{2}(\text { skormaksimal }+ \text { skorminimal }) \\
\mathrm{SB}_{\mathrm{X}}= & \text { Simpangan baku skor keseluruhan } \\
& \frac{1}{6}(\text { skormaksimal }+ \text { skorminimal }) \\
\mathrm{X} & =\text { Skor yang didapatkan }
\end{aligned}
$$

Tahapan analisis meliputi 4 tahapyaitu: pengumpulan data, reduksi data, penyajian data, dan penarikan kesimpulan. Langkah-langkah analisis data menurut Sugiono (2015), yaitu (1) pengumpulan datayaitu proses pengumpulan data dilokasi penelitian dengan menggunakan observasi, wawancara dan dokumentasi berdasarkan strategi pengumpulan data yang tepat; (2) reduksi datayaitu proses seleksi, pemfokusan, transformasi data kasar dari lapangan. Data yang telah direduksi akan memberikan gambaran tentang hasil pengamatan; (3) penyajian data merupakan kumpulan informasi yang disusun untuk mengarahkan ke proses penarikan kesimpulan; (4) penarikan kesimpulan yaitu proses perumusan jawaban dari rumusan masalah berdasarkan reduksi data dan penyajian data. Teknik analisis data disajikan pada Gambar 1.

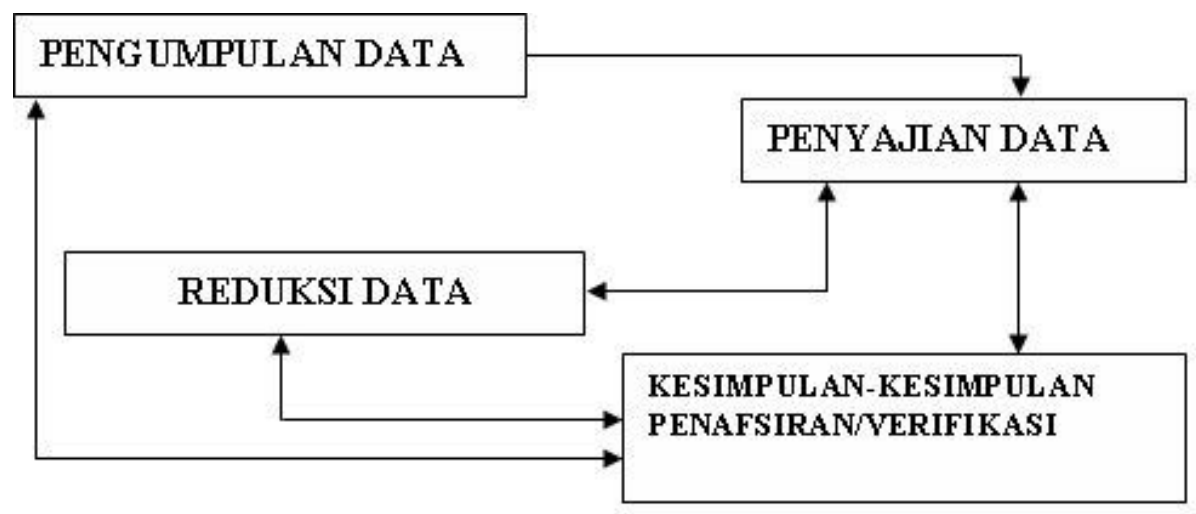

Gambar 1. Teknik Analisis Data

\section{HASIL DAN PEMBAHASAN}

Data tingkat pemahaman guru terhadap guru SMP di Salatiga terhadap KPS ditunjukkan pada Tabel 2.

Tabel 2.Tingkat Pemahaman Guru terhadap KPS

\begin{tabular}{lll}
\hline No & Kategori & Jumlah guru(\%) \\
\hline 1 & Sangat baik & - \\
2 & Baik & $50 \%$ \\
3 & Cukup & $50 \%$ \\
4 & Kurang & - \\
\hline
\end{tabular}

Hasil penelitian menemukan bahwa sebagian besar guru memahami pengertian KPS secara umum. Semua guru menyatakan bahwa KPS penting untuk diterapkan dalam 
pembelajaran. Menurut pendapat guru, KPS adalahketerampilan yang dimiliki peserta didik dalam setiap pembelajaran. Dengan dimilikinya KPS peserta didik dapat membangun konsep-konsep pengetahuan melalui penelitian ilmiah. KPSmengarah pada keterampilan mengobservasi, mengamati, mengklasifikasi, mengumpulkan data, mengelompokkan, mengkomunikasikan, mengajukan pertanyaan, dan menyimpulkan. Penerapan keterampilan-keterampilan tersebut mengajak peserta didik berpikir dan bertindak dalam menghadapi masalah. Guru juga menyatakan bahwa adanya penerapan KPS dalam pembelajaran dapat melibatkan peserta didik secara aktif dan melatih kemampuan berpikir.Rustaman (2015) menyatakan bahwa KPS melibatkan keterampilan-keterampilan lainnya seperti: keterampilan kognitif, manual dan sosial. Pada keterampilan kognitif peserta didik dilibatkan dalam melakukan keterampilan proses dengan menggunakan pikirnya. Keterampilan manual juga terlibat dalam keterampilan sains. Karena peserta didik diterapkan untuk melakukan pengukuran, penyusunan atau perakitan alat. Pada keterampilan sosial juga merupakan keterampilan sains karena peserta didik diajak untuk dapat melakukan interaksi dengan sesamanya dalam melaksanakan kegiatan belajar mengajar.

Pembelajaran biologi pada hakikatnya merupakan bagian dari pembelajaran sains yang mengarah pada hasil berupa produk, sikap dan proses. Peserta didik membangun konsep melalui serangkaian proses yang dapat membentuk sikap ilmiah (Sudarisman, 2015). Guru IPA termasuk guru biologi bertanggung jawab untuk mengembangkan proses pembelajarannya sesuai dengan hakikat sains dan membekali peserta didik keterampilan dalam melakukan proses sains yang disebut dengan keterampilan proses sains. Untuk dapat mempersiapkan pembelajaran sains yang ideal guru diharapkan memahami KPS, termasuk bagaimana cara mengembangkannya. Sejalan dengan Artayasa (2017) menyatakan bahwa guru harus mempunyai peranan penting dalam membantu mengembangkan hasil belajar sains yang baik. Konsep maupun keterampilan sains peserta didik, sehingga peranan tersebut dapat dengan maksimal. Guru harus memiliki kemampuan sains yang memandai.

Hasil analisis angket, sebanyak 50\% guru memiliki pemahaman tentang KPS dalam kategori baik dan 50\% guru memiliki tingkat pemahaman yang cukup tentang KPS. Hasil penelitian Aydogdu (2015) menunjukkan KPS guru yang lebih senior mengalami penurunan karena guru tidak mengembangkannya. Calon guru perlu memperoleh pemahaman yang baik tentang pembelajaran sains secara teori maupun secara praktek. Sebanyak64\% guru memahami tentang pengertian KPS dasar. Guru menyatakan bahwa KPS dasar merupakan keterampilan yang mendasar yang menjadi dasar bagi keterampilan proses dan harus dimiliki oleh peserta didik untuk dapat menguasai pembelajaran sains yang meliputi keterampilan mengamati, mengobservasi, 
mengklasifikasi, menggelompokkan, mengukur, dan mengkomunikasikan. Jika peserta didik memiliki keterampilan dasar maka peserta didik dapat melakukan keterampilan praktek ilmiah dengan baik dan benar. Aydogdu (2015) dan Raj \& devi (2014) menyatakan bahwa KPS dasar meliputi keterampilan observasi, mengamati mengklasifikasikan, mengukur, menyimpulkan, mengklasifikasi dan mengkomunikasikan, memprediksi, menggunakan hubungan ruang waktu dan menggunakan angka.

Ongowo (2013) menjelaskan bahwa KPS terintegrasi adalah keterampilan langsung yang digunakan dalam pemecahan masalahatau melakukan eksperimen sains. Sebagaimana istilah terintegrasi menunjukkan,peserta didik untuk dapat menggabungkan keterampilan proses sains dasaruntuk keahlian yang lebih besar. Peserta didik merancang alat,ketika mempelajari atau menyelidiki fenomena. Keterampilan terintegrasitermasuk dalam keterampilan mengendalikan variabel, mendefinisikan secara operasional, merumuskan hipotesis, menafsirkan data, bereksperimen,dan merumuskan model.Sebanyak57\%guru telah memahami mengenai KPS terintegrasi. Guru menyatakan bahwa KPS terintegrasi merupakan kemampuan menggunakan pikiran dan perbuatan secara efisien dan efektif untuk dapat mencapai sesuatu hasil tertentu. KPS terintegrasi merupakan KPS yang menuntut keterampilan yang lebih tinggi meliputi keterampilan merumuskan masalah, mengidentifikasi variabel, mengdeskripsikan hubungan antara variabel, mengendalikan variabel, merumuskan hipotesis, merancang penelitian, melakukan percobaan, memperoleh dan meyajikan data, menganalisis, dan dapat melakukan ekperimen. Peserta didik diharapkan memiliki KPS terintegrasi yang menggabungkan KPS dasar didalamnya.

Hasil wawancara menunjukkan bahwa guru telah berupaya melakukan pembelajaran yang mengarah padaKPS. Guru merencanakan kegiatan dalam Rencana Pelaksaan Pembelajaran (RPP). Guru menerapkan langkah-langkah metode ilmiah dan memperbanyak praktikum di luar kelas.Guru menyatakan telah mencoba menerapkan metode ilmiah sejak awal pembelajaran IPA. Dengan cara memberikan rangsanganrangsangan masalah berupa pertanyaan-pertanyaan yang dialami peserta didik dalam kehidupan sehari-hari. Untuk memecahkan masalah tersebut, peserta didik perlu melakukan praktikum. Peserta didik diminta untukmenyusun laporan hasil praktikumyang terdiri dari unsur judul, tujuan, dasar teori, alat dan bahan, prosedur percobaan, hasil pengamatan, dan kesimpulan. Melalui kegiatan inipeserta didik dapat terlatih untuk dapat memecahkan masalah. Astuti dkk (2016) berpendapat bahwa pemahaman konsep sains juga dapat diperoleh dari setiap percobaan seperti menggunakan lembar kerja ilmiah yang di dalamya memiliki kompetensi dasar, percobaan, analisis data hasil, kesimpulan dan penerapan dalam kehidupan sehari-hari. Sehingga peserta didik dapat terlatih dalam 
berkerja secara ilmiah. Dan diharapkan mampu membentuk sikap ilmiah dalam diri peserta didik.

Hasil wawancara guru dari 6 sekolah mengenai aspek KPS dalam pembelajaran dapat dilihat dari Gambar 2.

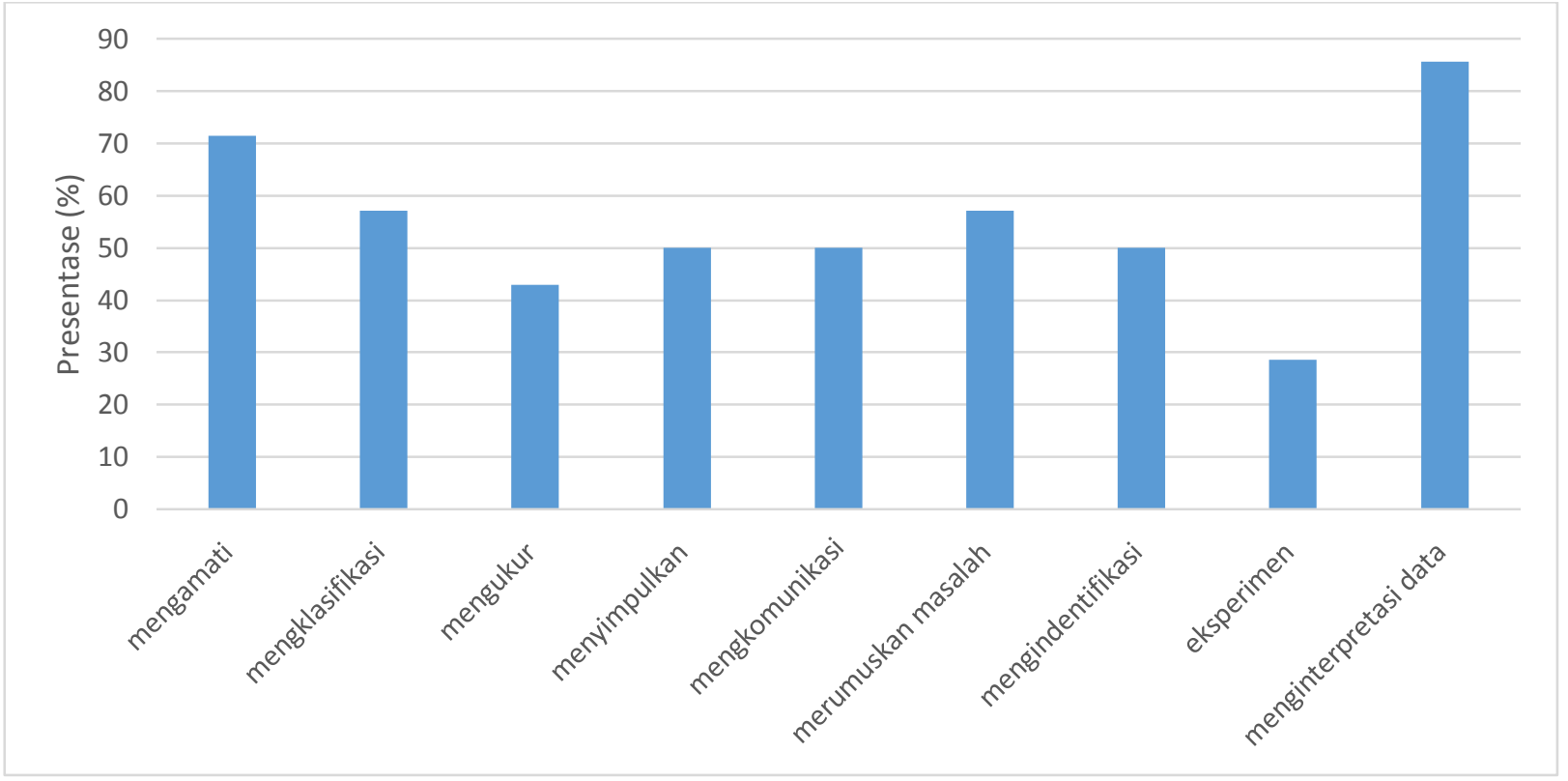

Gambar 2. Hasil Wawancara Penerapan Aspek KPS dalam Pembelajaran IPA

Gambar 2. menjelaskan bahwa penerapan guru dalam pembelajaran mengenai keterampilan menyimpulkan sebanyak 50\%.Guru sering mengarahkan peserta didik kepada keterampilan menyimpulkandengan cara memberikan pertanyaan-pertanyaan sesuai materi yang di jelaskan dan peserta didik menjawab, setelah itu guru meminta peserta didik membuat rangkuman dari hasil tanya jawab. Guru juga membagi peserta didik dalam kelompok dan meminta peserta didik untuk menyimpulkan dari hasil kerja kelompok.Sulastiani (2012) menyebutkan bahwa KPS keterampilan menyimpulkan merupakan keterampilan yang dilakukan oleh peserta didik pada saat proses belajar mengajar berakhir dengan memutuskan suatu keadaan objek atau peristiwa yang dipelajari berdasarkan fakta, konsep dan prinsip.

Wenno (2008) mendefinisikan mengamati sebagai keterampilan ilmu yang mendasar dalam mengobservasi atau mengamati. Peserta didik memilah-milahkan mana yang penting dari yang kurang atau tidak penting. Sebanyak $71 \%$ guru menyatakan sering mengajak peserta didik melakukan pengamati di dalam kelas maupun diluar kelas seperti mengamati permukaan daun dan guru mengajak peserta didik mengamati menggunakan indra penciuman, merabah dan mencicipi. Hal ini juga sama dengan pendapat Rustaman(2012) dan Ongowo (2013) menjelaskan bahwa KPS mengamati menggunakan lima indra untuk memperoleh karateristik organisme hidup dengan melalui penglihatan, 
pembau, pendengar, pengecap dan peraba, pada waktu peserta didik mengamati suatu objek tertentu.

Sebanyak 57\% guru sering mengajak peserta didik melakukan keterampilan mengklasifikasi/mengelompokkan suatu objek yang tak hidup dan hidup sesuai dengan ciri-ciri objek tersebut. Giarti (2015) mendefinisikan keterampilan mengklasifikasi sebagai kemampuan mengelompokkan atau menggolongkan sesuatuyang berupa benda, informasi, fakta dan gagasan.Beberapa contoh kegiatan mengklasifikasi antara lain: guru mengajak peserta didik mengklasifikasi tumbuhan menggunakan kunci determinasi, ada juga guru mengajak peserta didik mengklasifikasi abiotik dan biotik, tumbuhan monokotil dan dikotil. Rustaman (2012) memberikan contoh keterampilan mengkasifikasi misalnya ketika peserta didik mengolongkan makhluk hidup setelah mengenal ciri-ciri kemudian mengelompokkannya berdasarkan kesamaan, perbandingan, dan dasar penggolongan yang lain. Sebanyak $42 \%$ gurusering menerapkan keterampilan mengukur pada pembelajaran. Keterampilan mengukur diterapkan dengan mengajak peserta didikmelakukan pengukuran volume, berat, panjang dan suhu suatu benda. Alat yang digunakan untuk melakukan pengukuran antara lain jangka sorong, neraca dan mikrometer sekrup. Obyek yang diukur adalah benda-benda di sekitar. Peserta didik diharapkan dapat menggunakan alat ukur secara tepat. Selain itu, peserta didik dilatih untuk dapat membaca data dari hasil pengukuran. Giarti (2015) mendefinisikan keterampilan mengukur merupakan keterampilan yang mengajak peserta didik untuk dapat mengetahui sesuatu benda yang di ukur dari Panjang, luas, dan berat. Mahmudah (2016) dan Ongowo (2013) menyatakan hal yang sama bahwa keterampilan mengukur dapat dilakukan dengan berbagai kegiatan. Berkaitan dengan pengembangan dari satuan-satuan yang di ukuran yaitu :Panjang, luas, isi, waktu, berat dan volume dengan menggunakan alat ukur standar dan non standar.

Widya (2016) menyampaikan bahwa keterampilan mengkomunikasi merupakan laporan hasil percobaan dalam bentuk laporan terstruktur. Adapun hasil percobaan dapat dilakukan dengan mempresentasikan dengan bahasa yang baik dan sopan. Mampu memperlihatkan hubungan antara hasil dari percobaan. Keterampilan mengkomunikasi $50 \%$ guru sering menerapkan pemebelajaran yang mengajak peserta didik melakukan komunikasi. Dengan cara berdiskusi kelompok dan presentasi menggunakan power point guru juga melatih peserta didik untuk dapat berkomunikasi dengan baik kepada peserta didik lainnya guru juga mengajak peserta didik membuat laporan tertulis sesudah melakukan praktikum. Menurut Narut dkk (2017) KPS mengkomunikasi adalah peserta didik dilatih untuk dapat mengubah bentuk penyajian, dan melatih peserta didik memberikan data yang empiris dari hasil percobaan dengan menggunakan tabel, grafik 
atau juga dengan diagram. Melatih peserta didik juga dapat menyusun laporan secara sistematik.

Keterampilan merumuskan masalah $57 \%$ guru sering menerapkan dalam pembelajaran yang mengajak peserta didik merumuskan masalah dengan carapeserta didik dibentuk dalam kelompok dan memberikan pertanyaan bergiring untuk membantuh peserta didik memperoleh pemahaman merumuskan hipotesis, guru juga mengajak peserta didik untuk melihat sebuah persoalan dari materi yang dijelaskan oleh guru dan kemudian guru akan bertanya. Faizah (2015) menyatakan bahwa KPS merumuskan masalah merupakan suatu dugaan yang dapat diuji mengenai bagamaimana dan mengapa sesuatu terjadi. Aydogdu (2015) menerangkan KPS mengindentifikasi merupakan variabel yang memengaruhi hasil. Dan variabel yang diubah dalam percobaan. Sebanyak50\% guru sering mengajak peserta didik mengindentifikasi dan melaksanakan percobaan sesuai dengan tujuan kegiatan, mengetahui terlebih dahulu apa saja variabel yang berkerja seperti melakukan praktikum mengecambahkan biji kacang hijau.

Penerapan keterampilan eksperimen pada pembelajaran IPA. Penerapan aspek keterampilan eksperimen dalam pembelajaran masih sangat kurang. Hasil penelitian menemukan sebanyak $28 \%$ guru yang seringmelakukan kegiatan eksperimen. Guru mengajak peserta didik melakukan eksperimen dengan cara mengalami dan membuktikan secara mandiri sesuatu yang dipelajarinya.Eksperimen dilakukan denganmerangkai alat dan bahan, menggunakan alat dan bahan sesuai prosedur dan merapikan kembali alat dan bahan. Beberapa contoh eksperimen yang diterapkan dalam pembelajaran misalnya eksperimen berkaitan dengan pertumbuhan dan perkembangan, asam-basa, fotosintesis, pembentukan bayangan pada cermin. Melalui aktivitas yang dilakukan, peserta didik diajak untuk dapat berkembang sendiri sesuai dengan pengetahuan yang dimiliki. Menurut pendapat Sulastiani, dkk (2012) keterampilan ekperimen merupakan keterampilan yang mengarah kepada peserta didik. Guru memberikan kesempatan kepada peserta didik untuk melakukan sesuatu proses penelitian sederhana secara langsung.

Hasil penelitian mengenai aspek keterampilan menginterpretasi data sebanyak 85\%. Guru telah menerapkan pembelajaran yang mengarah pada keterampilan menginterpretasi data. Guru mengajak peserta didik melakukan kegiatan, dengan cara menggunakan dugaan atau kesimpulan sementara menggunakan logika. Hal ini sejalan dengan Widya (2016) bahwa KPS menginterpretasi data adalah gabungan informasi dari teori dan hasil percobaan, dan mencari suatu pola dalam sari pengamatan. Karamustafaoglu (2011) dan Tek \& Ruthven (2005) menjelaskan bahwa keterampilan sains merupakan keterampilan berpikir untuk dapat memperoleh informasi dan memperoleh masalah hinggadapat merumuskan hasil. Keterampilan yang memberikan penjelasan mengenai suatu objek, peristiwa dan pola dari informasi yang dikumpulkan, 
informasi yang dikumpul bisa berbagai bentuk. Sheeba (2013) berpendapat bahwa KPS menginterpretasi data mengacu pada pengorganisasian dan analisis data yang diperoleh dari mengumpulkan informasi mengenai suatu objek dan peristiwa yang mengambarkan situasi tertentu, dengan menarik kesimpulan dengan menentukan pola hubungan yang jelas dalam data.

Proses belajar mengajar sains juga terdapat faktor yang menghambat guru menerapkan KPS. Faktor utama adalah waktu belajar mengajar yang kurang. Sehingga guru sulit untuk dapat menerapkan KPS secara keseluruhan. Menurut guru, materi IPA cukup banyak, serta latarbelakang peserta didik yang berbeda-beda membuat guru sulit mengembangkan KPS. Beberapa guru juga menyampaikan bahwa faktor lain yang menghambat adalah belum dimilikinya Laboratorium dan lembar kerja peserta didik (LKS) yang mendukung guru dalam mengembangkan KPS. Sayekti dan Kinasih (2017) guru belum menanamkan KPS secara optimal pada peserta didik karena guru memiliki keterbatasan terkait dengan manajemen waktu dan manajemen kelas. Selain itu juga disebabkan oleh kurangnya pemahaman guru tentang KPS. Sedangkan Kurniawan(2013) mengungkapkan faktor-faktor yang menjadi kendala dalam penerapan KPS pada proses pembelajaran meliputi keterbatasan alat, rendahnya motivasi, minimnya pemahaman tentang KPS, dan kesulitan dalam membuat instrument penilaian KPS.

\section{SIMPULAN}

Simpulan dari hasil penelitian ini adalah sebanyak 50\% guru memiliki pemahaman tentang KPS dalam kategori baik dan 50\% guru memiliki tingkat pemahaman yang cukup. Guru telah melakukan kegiatan-kegiatan yang mengajak peserta didik ke arah pengembangan KPS. Dari aspek dengan nilai persentase tertinggi hingga terendah antara lain: menginterpretasi data (85\%), mengamati (71\%), mengklasifikasi $(57 \%)$, merumuskan masalah (57\%), menyimpulkan (50\%), mengkominikasi (50\%), mengindentifikasi $(50 \%)$, KPS mengukur (42\%), dan melakukan ekperimen (28\%). Aspek KPS telah diterapkan namun belum maksimal karena kurangnya waktu belajar mengajar, belum juga memiliki laboratorium dan juga lembar kerja peserta didik (LKS) dan rendahnya motivasi peserta didik.

\section{DAFTAR PUSTAKA}

Artayasa, I., Susilo, H., Lestari, U., \& Indriwatl, E. 2017. Profil Keterampilan Proses Sains Dan Hubungannya Dengan Hasil Belajar Sains Mahapeserta didik Pendidikan Guru Sekolah Dasar.Dalam. Proseding TEP dan PDs. Transformasi Pendidikan Abad 21. Malang, Indonesia. 
Astuti.Rina, Sunarno.Widha, dan Sudarisman.Sucianti. 2016. Pembelajaran IPA dengan Pendekatan Ketrampilan Proses Sains menggunakan Metode Eksperimen Bebas Termodifikasi dan Eksperimen Terbimbing Ditinjau dari Sikap Ilmiah dan Motivasi Belajar Peserta didik. Proceeding Biology Education Conference, 13(1): 338-345.

Aydogdu, B. 2015. The investigation of science process skills of science teachers in terms of some variables. Educational Research and Reviews, 10(5), 582-594.

Ergul, R., Simsekli, Y., Calis, S., Ozdilek, Z., Gocmenceleb, S., \& Sanli, M. 2011. The Effects Of Inquiry-Based Science Teaching On Elementary School Students Science Process Skills And Science Attitudes. Bulgarian Journal of Science and Education Policy, 5(1).

Faizah, U. 2015. Penerapan Pendekatan Saintifik melalui Model Project Based Learning Untuk Meningkatkan Ketrampilan Proses Dan Hasil Belajar Peserta didik Kelas IV SD Negeri Seworan, Wonosegoro. Scholaria, 5 (1) : 24-38.

Giarti, S. 2015 . Peningkatan Keterampilan Proses Pemecahan Masalah Dan Hasil Belajar Matematika Menggunakan Model PBL Terintegrasi Penilai Autentik Pada Peserta didik Kelas VI SD N 2 Bengle, Wonosegoro. Seminar Nasional Pendidikan Ekonomi dan Bisnis. Surakarta,Indonesia, 7 November 2015.

Kurniawan, A., \& Fadloli. 2016. Profil Penguasaan Keterampilan Proses Sains Mahapeserta didik. Proceeding Biology Education Conference, 13(1): 410-419.

Karamustafaoglu. 2011. Improving the Science Process Skills Ability of Science Student Teachers Using I Diagrams: Eurasian J. Phys. Chem. Educ, 3(1):26-38.

Musfiqon, H. 2012. Metodologi Penelitian Pendidikan. Jakarta : PT Prestasi Pustakaraya.

Mahmudah. Laely. 2016. Pentingnya Pendekatan Keterampilan Proses Pada Pembelajaran IPA di Madrasah. Elementary, 4(1).

Mardapi, Djemari. Prof.Ph.D. 2008. Teknik Penyusunan Instrumen Tes dan Nontes. Jogjakarta: Mitra Cendikia Press.

Narut, Y. F., \& Karyanto, P. 2017.Analisis Bahan Ajar Biologi Pada Materi Sistem Pencernaan Terhadap Potensi Pemberdayaan KPS Peserta didik SMA PL Santu Yosef Surakarta. Dalam. Seminar Nasional Pendidikan Sains II. Salatiga, Indonesia, 22 April 2017.p

Ongowo, O. R \& Indoshi, C.F. 2013. Science Process Skills in the Kenya Certificate of Secondary Education Biology Practical Examinations. Creative Education, 4(11):713717.

Rustaman, N. 2015 . Strategi Belajar Mengajar Biologi. Malang : Universistas Negri Malang.

Sudarisman, S. 2015. Memahami Hakikat Dan Karakteristik Pembelajaran Biologi Dalam Upaya Menjawab Tantangan Abad 21 Serta Optimalisasi Implementasi Kurikulum 2013. Jurnal Florea, 2(1): 29-35

Surianty. 1996. Keterampilan Proses IPA Peserta didik dengan Menggunakan Lingkungan dalam Pembelajaran IPA di Sekolah Dasar. Tesis. Bandung: PPS IKIP. Tidak diterbitkan. 
Sayekti, C.I., \& Kinasih, M.A. 2017. Kemampuan Guru Menerapkan Keterampilan Proses Sains Dalam Pembelajaran Ipa Pada Peserta didik Sekolah Dasar. Profesi Pendidikan Dasar. 4(1): 97 - 105.

Sugiyono. 2015. Metode Penelitian Kualitatif, kuantitatif dan Pengembangan. Bandung: Alfabeta.

Sulastiani, N \& Aslim. 2012. Analisis Keterampilan Proses Melalui Metode Eksperimen Dalam Pembelajaran Fisika Pada Peserta didik Kelas Viii Smp Negeri I Makassar. Jurnal Sains dan Pendidikan Fisika. 8(3) : 257 - 261

Sheeba. N.M. 2013. An Anatomy Of Science Skills In The Light Of The Challenges To Realize Science Instruction Leading To Global Excellence In Education. Educationia Confab, 2(4).

Tek, E.O \& Ruthven, K. 2005. Acquisition Of Science Process Skills Amongst Form 3 Students In Malaysian Smart And Mainstream Schools. Journal Of Science And Mathematics Education In S.E. Asia, 28(1).

Raj, G.R., \& Devi, N.S. 2014. Science Process Skills And Achievement In Science Among High School Students. Scholarly Research Journal For Interdisciplinary Studies, 2 (15).

Widya, W., \& Wati, N. 2016. Pengembangan Rubrik Asesmen Keterampilan Proses Sains Pada pemebelajaran IPA SMP. Jurnal Pendidikan Fisika Al-Biru Ni, 05(1) : 131-140.

Wenno I. H. 2008. Strategi Belajar Mengajar Sains Berbasis Kontekstual. Jogyakarta: Inti Media. 